\title{
Comparative Study of Sino-Japanese Folk Culture and Children's Education
}

\author{
Qin Wang \\ College of Foreign Languages, Yanan University, Yanan, Shaanxi, 716000
}

Keywords: Folk Culture; Children's Education; Sino-Japanese Comparison

\begin{abstract}
Folklore is a special cultural context, with national and regional features. Comparing the status quo of Chinese and Japanese folk culture in children's education, we can better find the ways and means of perfecting the value of folk culture education. In the process of the development of folk culture, we should cultivate the consciousness of children's participation, pay attention to the consciousness of children's local culture consciousness, and incorporate the folk culture with local characteristics into the primary and secondary school classroom, and can not ignore the excellent publicity works such as excellent film and television works and children's books. Learn from the Japanese animation culture propaganda model, so as to re-examine their own and local culture, to achieve its educational function optimization.
\end{abstract}

\section{Introduction}

Folklore is the civil society life in the transmission of cultural things in general. Folk culture, is a country or region a nation inherited from generation to generation grassroots culture, through the public oral, behavior and psychological performance of things. Folklore as a life of the group culture, the role of education is more subtle, through the daily activities of people in the attitude, language and behavior embodied in the individual's values and individual socialization of great influences. The most important feature of the distinction between different nations in the world lies in the unique folk culture of all ethnic groups. Although folk culture has the uniqueness of the nation, it also embodies the diversity of world civilization and culture. It is a country, a nation that stands in the forest of world civilization and is recognized by the world civilization.

China and Japan are a neighbor with water, belong to the East Asian "Confucian culture circle" and "Chinese culture circle", since ancient times close. During his meeting with the Japanese delegation, President Xi Jinping pointed out that the friendly foundation of China and Japan is in the civil society and encourages the younger generation to strengthen the non-governmental exchanges. Japanese expert Liu Deyou that folk is a cultural category, and cultural exchanges is the most easy in the minds of the two peoples set up a bridge, this bridge is a friendly bridge, mutual understanding of the bridge. Therefore, the education of folk culture is not only the realistic need of the development of nation-state, but also the objective requirement of sustainable discovery between different civilizations in the dialogue, but also the indispensable part of quality education and multicultural education.

\section{The Status Quo of Chinese Folk Culture in Children's Education}

In recent years, due to economic globalization and the impact of foreign culture, such as the antique palace there have been Starbucks, Kentucky Fried Chicken, McDonald's representative of Europe and the United States of food and cultural elements, Valentine's Day Rose has gradually replaced the Tanabata Festival Millennium good thoughts, Children for Harry Potter, One Piece and other foreign animation to understand and love, far more than the Lotus Lantern, Mulan from the military, gourd dolls on behalf of the traditional Chinese culture of domestic children's cartoons and books. The frequency of language use on the Internet, the frequency of use of English far more than Chinese, which shows that the United States led by the Western countries occupy the absolute 
control of Internet information, the formation of a monopoly on network information and dumping, language system is facing a history Since the most serious impact, half of the mix of foreign words to dominate the entertainment and media, network words, acronyms to the speed of light out of the network to the community, has become a young children's writing language and life language. China's folk culture in children's education, faced with internal and external problems.

As a result of the impact of Western culture, more families in order to let the children win at the starting line, more choices for children to learn foreign language, for the promotion of traditional Chinese culture does not mind, disciples, three words by how many generations can be proficient recited Promote the spirit and character of the books, in a new generation of children and children have no longer been taken seriously, children like Christmas, every holiday there are many Santa Claus in the street to give gifts to the children, for the traditional Chinese New Year , Ching Ming Festival, the origin of the Dragon Boat Festival and other folklore know little, foreign culture gradually replaced the children for the traditional folk culture. Over time, our folk culture system will face a great impact.

\section{The Status Quo of Japanese Folk Culture in Children's Education}

Over the past century, compared to other Asian countries, Japan's folklore has been considerable progress, and rapid development. The research content of the wide, fine categories, institutions of the public, as many people, attracted worldwide attention. In addition to the Japanese Folklore Society, with the study of deep, folk within the category of specialized, specialized research institutions have emerged, such as the song society, social heritage society, the Japanese written art academy, pragmatism research, Japan Folk Architecture Society, Buddhist folklore society, female folklore society, etc., in the Asia-Pacific region, it is difficult to find a similar second country. The richness of his writings is also sigh. There are many university professors who practice Japanese folklore. Almost every village has a collection of folklore rooms and museums. Some of the most famous scholars, also published a large number of multi-volume folklore personal anthologies such as "set Ben Liu Tian Guo Gong Ji", "folding letter Fuji Complete Works", "Miyamoto a book" and so on. Since the 1980s, Japanese folklore research, in addition to more detailed research, the obvious to the multi-disciplinary penetration, there have been many folklore cross research topics and achievements, such as education, history, psychology, literature, ethics, Law and so on. In addition, the study of the eyes more concerned about the neighboring countries and regions. China is the main object of their research. Such as Fukuda Asaka men led by the Sino-Japanese Central Donghai folklore studies, China Jiangnan village folklore research. Subsequently, comparative folklore, Asian studies in Chinese and Japanese folklore, also quietly rising. After World War II, Japanese folklore the hope of reconstruction in the education reform, the abolition of the history of history, a new "social science". The folklore discipline into the general education of the people, so that folklore quickly become a from primary school to university, from knowledge to academic research systematic education project, a understanding of the motherland, love the country's local education course. The purpose is to change the prevailing national pessimistic, fatalistic concept. We think that national consciousness transformation starts from education and starts from child, and Japanese folklore learns from education and infuses into social course. Thus, Japanese folklore and children's education combined earlier, in this area has a wealth of experience.

\section{The Japanese Folk Culture Education in Our Country}

Japan is one of the first countries in the world to propose the protection of cultural heritage (including intangible cultural heritage) and the world's most recognized cultural heritage. And children's participation as an important part of which has been the attention of the Japanese government and civil society groups. Such as a large-scale ceremonial event of the Hachiman Shrine in the Miyagi Prefecture, Miyagi Prefecture, Miyagi Prefecture, Japan, which is a large-scale festival event, Years of history, designated by the state as "intangible cultural property", is praying grain bumper and family safe folk activities. From the beginning of the 80's Miyagi Prefecture, 
Japan's primary school students to participate in the main, this festival into the school's social, sports, art and other courses. Article 3 (3) of the Interim Measures for the Assessment of the Representative of State-level Intangible Cultural Heritage in China also points out that "the inheritance of the intangible cultural heritage through the means of social education and school education can continue to be Living cultural traditions are inherited and developed in the relevant communities, especially among young people.

Meta-cultural communication and communication, so that we find their own roots and cultural identity, and the national consciousness of the first to start from the children, focusing on children's local cultural awareness of the enlightenment and improve their awareness of participation. CCTV readers, Chinese characters contest, poetry and other programs, are to primary and secondary school students for the object, set off a national learning traditional Chinese culture boom, but also awakened people for the traditional culture and traditional culture of the importance of education. In addition, the traditional Chinese handicrafts, such as mud people Zhang, sugar people such folk skills, there are some local characteristics of folk art is also necessary through the primary and secondary school classroom education approach to inheritance and carry forward. Such as the northern Shaanxi Ansai drum, has long been included in the Ansai County primary school students in the course of physical education. In the era of pan-entertainment, this is not just the protection of folk, but also the children's hometown of love and the spirit of the local culture of the Enlightenment. The protection and tradition of folk culture as a comprehensive project, in which the participation of children to ensure that the national and regional cultural subjectivity, childhood is the concept of life, the formation of values and personality shaping the most important stage, to develop children's local cultural awareness and Identity, especially in primary and secondary education, the initial accumulation of knowledge and culture links, should be included in a certain traditional culture teaching content.

The education of folk culture for young people involves many elements of synthesis. Must be a combination of formal education (school) and non-formal education (community, family, etc.), the combination of book knowledge and practical experience, so that children from the emotional interest, and gradually into the rational understanding of the stage, so that the real understanding of the intangible cultural heritage Importance, as its successor. Excellent film and television works and children's books and other external publicity on the promotion of folk culture education, animation as a very suitable for children to watch, by the children's favorite art form, its educational function can not be overlooked. This point is on the Japanese animation culture propaganda model worthy of our reference.

Japanese animation development model has distinctive national characteristics. On the one hand the national culture into a "cultural symbol", scattered in every corner of each animation works. Such as delicious sushi, gorgeous kimono, flying cherry blossoms everywhere, everywhere "bubble soup culture". Some works because of the relatively large time span, and even Japan will be a year of customs are displayed again: spring cherry congress, summer Bon Festival, autumn leaves, winter stove and New Year's Day shrine visit And so on, from the diet to wear and then to Japan's daily living customs, almost all aspects of the cover, which did not show the mountain did not dew to complete the construction of national cultural image. In addition, the imperial house culture, the second element, cure and other cartoon language also as a cultural output, become the current Chinese young people popular language.

China's animation industry, although the current and Japan have a certain gap, but also appeared such as "Kung Fu Panda" so full of Chinese cultural elements of the excellent animated film. The film's preparation period of up to 15 years, during which the producers of China's traditional culture, art, architecture and landscape. In order to restore the feelings of Chinese martial arts and animation production, animation members have participated in the Taijiquan training courses, repeatedly watched the domestic high-quality animation, "Nezha downtown" and "Temple". China's folk culture, although there is still a long way to go, but we have been in progress, I believe that in the near future, folk culture will be inherited through the form of children's education, our children can understand the Chinese culture Unique charm and as a pride, and toward the international 
community to carry forward and spread the Chinese nation's outstanding folk culture, to speed up its pace towards the world.

\section{Conclusion}

Through the comparative study of Chinese and Japanese folk culture and children's education, it is possible to grasp the development of folk culture in China and Japan since the new century and explore the similarities and differences between the two countries' folklore education and contribute to mutual understanding and cultural exchange between the two countries The In the process of accelerating the globalization process, this study is conducive to enhancing our nationals on the country, the local culture of identity, but also conducive to resist the impact of foreign culture. Children's education is a good form of folklore culture, which is the realistic need for the development of school-oriented education and an important measure for the full implementation of quality education. In particular, the school education in the process of understanding, understanding, feeling and the use of folklore, to achieve the diversity of cultural knowledge and richness of the folk culture has a rational sublimation and theoretical purification. Folklore culture is disseminated through education and is vital to the local economy, the activation of culture and the cultivation of artistic talents.

\section{Acknowledgements}

This article is the 2016 Department of Shaanxi Education special research project "Sino-Japanese folk culture and children's education comparative study" results, the project number: 16JK1849

\section{References}

[1] Feng Tong. On the inheritance of Japanese folk culture and its revelation to China, Dalian modern history research [M]. Beijing Normal University, 2010 (00)

[2] Duan Kunshan. Concerned about the future development of the Japanese children's primary education - to the Japanese cultural and educational exchanges Random [J]. Shanxi Education; Management, 2010 (23)

[3] Guo Fachi. Japanese children's spiritual education and crisis response [J]. Education and Education, 2003 (12)

[4] Zhong Qiquan. Japan "and" cultural and educational picture - Japanese education scholar Professor Nakamura Tetsu [J]. Global Education Outlook, 2007 (06)

[5] Li Yongting. Educational value of folk culture [D]. Shandong Normal University, 2014 